\section{Discontinuing drugs before surgery}

A

NAESTHETISTS are increasingly confronted with surgical patients with complex medical problems, often treated with a myriad of drugs. Administration of safe and effective anaesthesia requires an understanding of patient pathophysiology and the pharmacology of potential drug interactions. One strategy of risk management in such patients is to reduce the potential for adverse interactions by discontinuing selected drugs before surgery. The objective of this review is to provide insight into the practice of discontinuing drugs before surgery, with particular reference to those classes of drugs for which this practice has been advocated or is controversial.

\section{General considerations}

It is assumed that maintenance drug therapy has been prescribed for a patient to treat a specific condition and that this treatment has been optimized and that the condition is relatively stable. Experience has shown that, for the most part, in the perioperative period this stability is best maintained by continuation of these medications uninterrupted wherever possible.

When it is deemed necessary to withhold medication preoperatively, the anaesthetist must consider the pharmacokinetic profile of the drug to ensure sufficient time is allowed for metabolic clearance. Ideally this is three to five half-lives. This may be complicated by the presence of active metabolites.

\section{Oral medications and NPO status}

Historically, it has been the practice to fast adult patients, for six hours or longer prior to surgery, to reduce the risk of pulmonary aspiration of gastric contents. Nulla per os (NPO) often included oral medications (inadvertently or by design). Critical examination has resulted in a relaxation of this policy and it would seem that most anaesthetists normally allow clear fluids up to two to three hours preoperatively in patients with a functioning gastrointestinal tract. ${ }^{1-3}$ Therefore, NPO status per se should not be considered a valid reason for discontinuing maintenance drug therapy preoperatively. For patients whose gastrointestinal tract is non-functioning, consideration to alternative drugs or routes of delivery should be considered.
Drugs affecting the cardiovascular system

Concern about the body's response to anaesthetic drugs, shifts in intravascular volume, and manipulations of the sympathetic nervous system in the presence of drugs affecting the cardiovascular system, has given way to evidence of the benefits of uninterrupted antihypertensive and antianginal therapy in the perioperative period. In particular, withdrawal syndromes associated with abrupt cessation of $\beta$-blockers and $\alpha_{2}$-agonists are avoided, but also the risk of manifestation of underlying hypertension or myocardial ischaemia in the perioperative period is lessened by the continued administration of most antihypertensive and antianginal agents.

\section{Renin-angiotensin system ( $R A S)$ inhibitors}

The RAS is a homeostatic mechanism for blood pressure control that is activated in response to a perceived reduction in effective circulating volume. The result is a biochemical cascade culminating in the formation of angiotensin II. The immediate effect of angiotensin II, mediated through the angiotensin II receptor $\left(\mathrm{AT}_{1}\right)$ is a rapid pressor response, due to direct vasoconstriction and enhancement of peripheral noradrenergic effects. A second, slower pressor effect is exerted through stimulation of aldosterone secretion and $\mathrm{Na}^{+}$ and water reabsorption to increase intravascular volume. ${ }^{4,5}$ The role of the RAS in maintenance of blood pressure in the normal, sodium replete, well hydrated individual is minimal.

Angiotensin converting enzyme (ACE) inhibitors, which inhibit the RAS, are now the cornerstone of therapy for congestive heart failure and are important in the therapy of hypertension and coronary artery disease as well. ${ }^{4}$ Continuation of ACE inhibitors in the immediate preoperative period has been questioned after several case reports of unexpected, severe hypotension and/or bradycardia during anaesthesia in patients receiving ACE inhibitors, ${ }^{4}$ and clinical studies demonstrating hypotension and poor tolerance of hypovolaemia during anaesthesia. ${ }^{6,7}$ As a result, many anaesthetists withhold ACE inhibitors before surgery. ${ }^{8}$

Maintenance of blood pressure and cardiac output during general or neuraxial anaesthesia are at least par- 
tially dependent on the RAS,, 10 as well as being influenced by effective blood volume, sympathetic nervous system (SNS) activation, and vasopressin secretion. ${ }^{10}$ Furthermore, the RAS may directly affect responses to SNS activation since ACE inhibitor premedication significantly attenuates noradrenaline release in response to surgical stress. ${ }^{5,11}$ Clearly there is some interaction among these systems resulting in blood pressure homeostasis and a decreasing influence of any one factor (e.g., effective blood volume) is compensated for by increased activity in the others. Simultaneous inhibition of multiple arms of the homeostatic system such as with hypovolaemia, SNS suppression from general or neuraxial anaesthesia, and RAS blockade with an ACE inhibitor leaves little with which to compensate and blood pressure falls.

Clinical studies have consistently shown a higher incidence and greater magnitude of hypotension on induction of anaesthesia in patients who have received preoperative $A C E$ inhibitors than in patients receiving other antihypertensives or those in whom regular ACE inhibitor therapy was withheld. 6,7,12 The decline in blood pressure is associated with decreased systemic vascular resistance and decreased central filling pressures and usually responds well to hydration and/or moderate doses of vasopressor. Hypertensive patients undergoing cardiac and major vascular surgery may be particularly susceptible to hypotensive episodes. ${ }^{6,12}$ In contrast, in patients with congestive heart failure treated with ACE inhibitors until the day of surgery, the incidence of hypotension with anaesthesia induction is not high. ${ }^{13}$ Hypertensive patients who are being treated with ACE inhibitors in conjunction with two or more additional antihypertensive drugs may be particularly prone to hypotension with induction. ${ }^{6}$ This may reflect the severity of their disease or additive effects of the associated medications. Patients taking an ACE inhibitor concurrently with amiodarone may at risk for severe hypotension. ${ }^{14}$

Although RAS activation contributes to maintenance of blood pressure during anaesthesia, surgery is a much more potent activator of the RAS, particularly in conjunction with controlled hypotension, cardiopulmonary bypass, or aortic cross clamping. ${ }^{4}$ In such circumstances, RAS activation may have deleterious effects on oxygen delivery, myocardial performance and renal function. ${ }^{5}$ Activation of the RAS may in part be responsible for haemodynamic instability, abnormal oxygen utilization, and renal dysfunction associated with abdominal aortic surgery. ${ }^{12,15}$ Licker et al. ${ }^{15}$ have shown that enalapril, at doses which produced $>90 \%$ ACE inhibition, considerably improved cardiac output and oxygen delivery during aortic cross clamp. Perhaps more important was the better preservation of renal blood flow and glomerular filtration which persisted into the postoperative period. Angiotensin converting enzyme inhibitor mediated attenuation of the sympathetic response to surgical stress may also be beneficial. ${ }^{11}$

Losartan is an orally available $\mathrm{AT}_{1}$ antagonist, recently introduced to North America. Data on anaesthetic interactions are limited but its therapeutic profile is similar to ACE inhibitors so it is likely to behave similarly. Unlike ACE inhibitors, losartan does not inhibit bradykinin breakdown so one could speculate there may be a lower incidence of severe hypotension during anaesthesia. Angiotensin II activation of $\mathrm{AT}_{2}$ receptors, unopposed by losartan, may also have an influence. ${ }^{5}$ More studies are needed, however.

Although perioperative RAS blockade may be associated with severe hypotension during anaesthesia, data suggest that these episodes are brief and are effectively treated with restoration of intravascular fluid volume and/or vasopressors. Although brief interruption of ACE inhibitor therapy appears to be well tolerated, ${ }^{7}$ continuation of ACE inhibitors perioperatively may improve regional blood flow and oxygen delivery and preserve renal function in those patients at risk. For patients receiving RAS inhibitor therapy it is reasonable not to withhold their medication routinely preoperatively. Exceptions to this might include those patients taking an ACE inhibitor in conjunction with amiodarone, patients on multiple $(\geq 3)$ antihypertensives, or patients in whom even a brief period of hypotension is unacceptable. For surgical patients receiving RAS inhibitors, the importance of optimal fluid loading during anaesthesia must be emphasized.

\section{Diuretics}

Diuretics are often used as first line therapy for hypertension and as an adjunct to congestive heart failure therapy. The antihypertensive effects of diuretics are at least partly related to long term changes in vascular resistance as a result of altered $\mathrm{Na}^{+}$handling. Patients taking diuretics for treatment of mild hypertension, dependent oedema, or mild congestive heart failure rarely become symptomatic if their morning dose is omitted on the day of surgery and are invariably grateful for the absence of urinary frequency while waiting to enter the operating room! An exception to this may be patients for whom diuretics constitute a part of the treatment for chronic renal failure, in which case withholding the drug may not be appropriate.

\section{Antiarrhythmics}

The high incidence of side effects associated with antiarrhythmic drugs means that they are rarely prescribed for benign arrhythmias. As such, consideration 
of discontinuing these drugs preoperatively is discouraged. With the exception of amiodarone, the deleterious effects of most antiarrhythmics associated with anaesthesia (cardiac depression and prolonged neuromuscular blockade) are mild and predictable and are easily managed. Where there is any suggestion of antiarrhythmic toxicity it would be prudent to ensure that drug levels are within the appropriate therapeutic range and any electrolyte abnormalities are corrected. When prolonged fasting is anticipated and a parenteral formulation of the drug is not available (e.g., quinidine), consultation with the attending cardiologist is suggested and consideration should be given for substitution with a parenterally administered drug of the same class (e.g., disopyramide or procainamide). If antiarrhythmic therapy is to be withdrawn in anticipation of cardiac electrophysiological mapping under anaesthesia, it should be done with consideration of the $T_{1 / 2}{ }^{B}$ and the influence of active metabolites. ${ }^{16}$

Amiodarone poses some special problems to the anaesthetist. It is an iodinated benzofuran derivative and a structural analog of tri-iodothyronine. Indeed, some of its toxicity resembles the effects of hypothyroidism and may be related to interference with nuclear thyroid hormone receptors. Toxicity associated with chronic use includes pulmonary fibrosis, thyroid dysfunction, peripheral neuropathies, and hepatitis. Amiodarone possesses non-competitive $\alpha$ and $B$-adrenergic blocking effects, likely related to a reduction in receptor density rather than a change in affinity, and produces a progressive bradycardia independent of receptor blockade. These effects may be responsible for the cardiovascular collapse under anaesthesia that has been reported in some patients. ${ }^{14,17}$ Hypotension due to profound arterial and venous vasodilation not responsive conventional doses of vasopressors, and atropine resistant bradycardia requiring ventricular pacing are most often reported following cardiopulmonary bypass.

A highly lipophilic drug, amiodarone becomes concentrated in tissues and is eliminated very slowly with

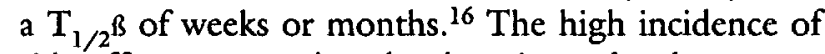
side effects means that the drug is used only to treat serious arrhythmias or when first line therapy has been ineffective. As a result, preoperative discontinuation of amiodarone as a means of avoiding adverse interactions during anaesthesia is impractical. Withholding concurrent medication which may have additional depressive effects on the cardiovascular system (e.g., ACE inhibitors) may be prudent. ${ }^{14}$ Life threatening complications associated with amiodarone and anaesthesia have been largely confined to those patients undergoing cardiac surgery. ${ }^{17}$ The anaesthetist con- fronted with such a patient should be prepared to treat hypotension and low cardiac output with "industrial" doses of vasopressors or inotropes and resistant bradycardia with a pacemaker.

\section{Drugs affecting haemostasis}

Although not necessarily a contraindication to general anaesthesia per se, impaired haemostasis presents concerns where regional anaesthesia is contemplated and is a risk from the surgical perspective. The drugs of concern may range from non-steroidal anti-inflammatory drugs (NSAIDs) or low-dose heparin to full heparinization or warfarin therapy, to treatment with fibrinolytic agents. Any decision to hold preoperative NSAIDs or anticoagulants must be based on an assessment of the underlying condition for which the treatment is prescribed $v s$ the risk posed to the successful management of anaesthesia and surgery.

\section{NSAIDs}

Non-steroidal anti-inflammatory drugs are prescribed for a wide range of conditions, including cerebral thromboembolic conditions, coronary artery disease, and a variety of musculoskeletal disorders. They act through inhibition of prostaglandin synthesis. Peripherally, this results in anti-inflammatory and analgesic effects, impaired platelet function (and altered haemostasis) and, in certain circumstances, to reduced renal blood flow. In the central nervous system, inhibition of prostaglandin synthesis may also have antinociceptive effects.

In the past, it was advised that NSAIDs be withheld perioperatively because an increased risk of renal failure was feared. This appears only to be a risk in those patients with other predisposing factors, including heart failure, hypovolaemia, cirrhosis, sepsis, or preexisting renal dysfunction. ${ }^{18}$

Cyclo-oxygenase inhibition by NSAIDs results in impaired platelet function and abnormal bleeding times. This may be of concern to the anaesthetist because of a risk of increased surgical bleeding or bleeding associated with regional anaesthesia. Indeed, there has been considerable debate on the subject. 8,18-20 Haematoma associated with neuraxial anaesthesia is a rare event and the literature suggests that NSAID therapy by itself does not contribute to increased risk. However, concurrent or subsequent anticoagulation in a patient already receiving an NSAID may introduce a considerable risk necessitating preoperative withdrawal of the NSAID.$^{20}$ Because of a lack of predictive value for risk of haemorrhage, bleeding times are of little use in evaluating whether or not to proceed with regional anaesthesia. $8,18,20$ 
In the patient taking NSAIDs preoperatively, the risks of possible impaired platelet function, altered renal function, and gastrointestinal bleeding must be weighed against possible protective effects against stroke or myocardial ischaemia and the analgesic/antiinflammatory action in patients with musculoskeletal pain. Overall, in patients who are already taking NSAIDs, the risk of adverse sequelae related to continuation of the drugs preoperatively would appear to be slight. For patients taking aspirin as stroke or myocardial ischaemia prophylaxis, the benefits likely outweigh the risks. For patients taking NSAIDs for less serious conditions, the answer is not so clear. However, unless the surgery puts the patient at particular risk for increased or catastrophic bleeding, or impaired renal function, it is reasonable to continue NSAIDs up to the morning of surgery.

\section{Anticoagulants}

Systemic anticoagulation with heparin or coumadin may be encountered in patients presenting for surgery or may be anticipated to be introduced intraoperatively (i.e., heparin) during major vascular surgery.

Preoperative heparin therapy takes the form of lowdose, sc heparin, usually for deep venous thrombosis prophylaxis, or full iv heparinization for treatment of thromboembolic disorders or as perioperative replacement for coumadin therapy. Heparin is a large mucopolysaccharide that forms a complex with antithrombin III which in turn binds thrombin, and factors IXa, XIa, and XIIa to interrupt the coagulation pathways. Because of the risks of haemorrhage, iv heparin therapy is discontinued prior to most elective surgery. The half-life of heparin is short (one to five hours) and stopping the drug four to five hours preoperatively is usually sufficient although normalization of the PTT should be confirmed. If necessary, rapid reversal of heparin activity may be achieved with ip protamine.

Full heparinization is generally considered a contraindication to regional anaesthesia, however the approach to $s c$ heparin is more controversial. $8,19,20$ Overall, the risk of haematoma associated with regional anaesthesia in patients receiving $s c$ heparin is slight, but prudence is advised and each case should be considered on an individual basis.

Coumadin interferes with the metabolic regeneration of vitamin $\mathrm{K}$, resulting in depletion of the vitamin $\mathrm{K}$ dependent clotting factors, II, VII, IX, and X. Coumadin is most often encountered as a treatment/prophylaxis for venous or arterial thromboembolism. Obviously, the patient receiving warfarin therapy is at risk for increased bleeding related to surgery or neuraxial blockade. Because the effect of coumadin takes several days to reverse, it is advised that it be discontinued several days before surgery and that the patient be placed on heparin therapy in the interim. If necessary, a more rapid reversal of coumadin's effect may be achieved with vitamin $\mathrm{K}$ and/or fresh frozen plasma.

\section{Fibrinolytic drugs}

Therapy with fibrinolytic drugs (e.g., streptokinase, urokinase, tissue plasminogen activator) is usually reserved for life-threatening conditions such as acute myocardial infarction or massive pulmonary embolus. Because of the risks of massive haemorrhage, fibrinolytic therapy is contraindicated before surgery. Unfortunately, many patients receiving fibrinolytic drugs find themselves in the operating room undergoing emergency cardiac surgery. Since discontinuing fibrinolytic therapy is not an option, perioperative use of antifibrinolytic agents such as aprotinin has been advocated to limit surgical blood loss. ${ }^{20}$

\section{Hypoglycaemic agents}

Glucose homeostasis in the diabetic patient involves interaction among multiple factors including calorie intake, the internal hormonal milieu, and exogenously administered hypoglycaemic agents (i.e., insulin or oral hypoglycaemics). The process of surgery disrupts the first two and, in order to maintain equilibrium, some adjustment of the latter is required.

\section{Insulin}

The perioperative management of insulin dependent (Type I) diabetics has been extensively reviewed elsewhere. ${ }^{21,22}$ Because of stress induced metabolic changes and altered calorie intake, prediction of insulin requirements in diabetic patients undergoing surgery is difficult. During prolonged surgery, absorption of $s c$ insulin may be unpredictable because of alterations in local blood flow induced by changes in body temperature and haemodynamics. The most rational approach to insulin therapy in the insulin dependent diabetic presenting for surgery is substitution of the usual morning dose of $s c$ insulin with a continuous $i v$ infusion of insulin and dextrose, coupled with frequent blood glucose analysis and adjustments as indicated. ${ }^{21,22}$

\section{Oral hypoglycaemic agents}

Non-insulin dependent (Type II) diabetics have endogenous insulin but are relatively resistant to it. They are less susceptible to diabetic ketoacidosis and tend to have less dramatic fluctuations in blood sugar. Perioperative management focuses on avoidance of dehydration and a hyperosmolar state or hypoglycaemia, rather than tight 
control of blood sugars. Treatment of Type II diabetes often includes oral hypoglycaemics, either derivatives of sulfonylurea or biguanides.

The sulfonylureas are the most frequently encountered oral hypoglycaemics. They stimulate pancreatic release of insulin and may reduce hepatic clearance of the hormone to further enhance levels. Sulfonylureas may cause severe hypoglycaemia, particularly in a fasting surgical patient. Their tendency to do this is proportional to the drug's half-life. Chlorpropamide has a half-life of 24 to $48 \mathrm{hr}$ while the second generation analogues such as glyburide and glipizide have halflives of three to six hours, although their hypoglycaemic action may persist for as long as 12 to $24 \mathrm{hr}$. Because of the tendency towards hypoglycaemia, oral hypoglycaemics should be withheld before surgery. In the case of long acting agents such as chlorpropamide, the drug should be withheld beginning on the day before surgery. With glyburide or glipizide, it is sufficient to withhold on the morning of surgery if the patient is to get a fluid breakfast and the surgery is later in the day, or in the case of early morning surgery, withhold the night before. Intravenous fluids and frequent monitoring of blood sugars is suggested.

Metformin is the only biguanide now clinically available. Technically it is antihyperglycaemic rather than hypoglycaemic and does not cause hypoglycaemia even in large doses. It acts to reduce blood glucose levels by increasing the effect of insulin on peripheral tissues and inhibiting gluconeogenesis. Since it does not cause hypoglycaemia, it is usually not necessary to stop the drug preoperatively, however it may cause lactic acidosis in patients undergoing a prolonged fast which may preclude its use postoperatively in some circumstances.

\section{Drugs affecting the central nervous system}

Drug therapy targeted at the central nervous system includes drugs for the treatment of seizure disorders, movement disorders such as Parkinsonism, and psychiatric disturbances. Adverse interactions with anaesthesia that have been attributed to most of these drugs are well described and may be avoided without discontinuing therapy preoperatively. ${ }^{8}$ One exception to this may be the monoamine oxidase inhibitors (MAOIs), used in the treatment of some affective disorders.

\section{Monoamine oxidase inbibitors}

Monoamine oxidase (MAO) is an intracellular enzyme responsible for metabolism of catecholamines such as dopamine, serotonin, and noradrenaline. Inhibition of the enzyme by MAOIs results in accumulation of these neurotransmitters in the releasable pool.
Three types of potentially serious interactions during anaesthesia have been described in patients taking MAOIs. ${ }^{23-25}$ Indirect acting sympathomimetic drugs such as ephedrine may cause the release of massive amounts of noradrenaline resulting in a hypertensive crisis. This has not been seen with direct acting agents such as phenylephrine. The other two types of reactions have been associated with opioid administration. The first, and more serious, has been most often reported with meperidine and dextromethorphan, and consists of an excitatory state with agitation, hypertension, hyperpyrexia, rigidity, convulsions, and coma. A second, depressive phenomenon has also been described in the presence of MAOIs and opioids. Consisting of respiratory depression, lethargy, hypotension and coma, it may be secondary to elevated opioid levels due to MAOI-induced impairment of hepatic microsomal enzymes.

This potential for fatal interactions with MAOIs led to the dogma of complete withdrawal of MAOIs before surgery under anaesthesia. ${ }^{23,24}$ First generation MAOIs, including tranylcypromine, phenelzine, pargyline and isocarboxazid were non-selective (there are two isozymes of MAO, MAO-A and MAO-B, having somewhat differing substrate affinities) and irreversible. As a result, a period of two to three weeks abstinence was recommended, with potentially serious psychiatric consequences.

Recently, reversible, specific inhibitors of MAO-A (RIMAs) have come into use. Although data on interactions with anaesthetic drugs are limited, it has been suggested that RIMAs may be less likely to produce serious interactions with meperidine. ${ }^{23}$ The short halflife of the new RIMAs $\left(T_{1 / 2}{ }^{B}\right.$ of two hours for moclobemide) makes preoperative withdrawal of the drug a more convenient exercise.

Recent experience with patients taking MAOIs seems to indicate that their anaesthetic can be safely managed by avoidance of known triggering agents without resorting to preoperative withdrawal of the MAOI. As an alternative, in those patients taking RIMAs, stopping the drug on the day of surgery is likely sufficient to limit adverse anaesthetic reactions without jeopardizing their psychiatric state. ${ }^{25}$

\section{Conclusions}

In the majority of cases, patients should continue their usual medications preoperatively. Exceptions to this have been alluded to. Of greater importance is the recognition of potential adverse interactions with anaesthesia and the modification of the anaesthetic technique to reflect this. When it is necessary to withhold a drug preoperatively, knowledge of the $\mathrm{T}_{1 / 2^{\mathrm{B}}}$ 
and the behaviour of any metabolites is required to ensure the expected decline in drug activity. Whenever drug levels are allowed to decrease preoperatively, a resurgence of symptoms of the underlying pathology must be anticipated. Communication with the prescribing physician and surgeon may be appropriate.

\section{References}

1 Maltby $J R$, Sutherland $A D$, Sale JP, Shaffer $E A$. Preoperative oral fluids: is a five-hour fast justified prior to elective surgery? Anesth Analg 1986; 65: 1112-6.

2 Goresky GV, Maltby JR. Fasting guidelines for elective surgical patients (Editorial). Can J Anaesth 1990; 37: 493-5.

3 Green CR, Pandit SK, Schork MA. Preoperative fasting time: is the traditional policy changing? Results of a national survey. Anesth Analg 1996; 83: 123-8.

4 Kellow $N H$. The renin-angiotensin system and angiotensin converting enzyme (ACE) inhibitors. Anaesthesia 1994; 49: 613-22.

5 Colson $P$, Ryckwaert $F$. Angiotensin-converting enzyme inhibitors and the renin angiotensin system. Current Opinion in Anaesthesiology 1995; 8: 83-7.

6 Colson $P$, Saussine $M$, Séguin, Cuchet $D$, Chaptal $P-A$, Roquefeuil $B$. Hemodynamic effects of anesthesia in patients chronically treated with angiotensin-converting enzyme inhibitors. Anesth Analg 1992; 74: 805-8.

7 Coriat $P$, Richer $C$, Douraki $T$, et al. Influence of chronic angiotensin-converting enzyme inhibition on anesthetic induction. Anesthesiology 1994; 81: 299-307.

8 Stafford Smith M, Muir H, Hall R. Perioperative management of drug therapy. Clinical considerations. Drugs 1996; 51: 238-59.

9 Miller ED Jr, Longnecker DE, Peach $M J$. The regulatory function of the renin-angiotensin system during general anesthesia. Anesthesiology 1978; 48: 399-403.

10 Carp $H$, Vadbera $R$, Jayaram $A$, Garvey $D$. Endogenous vasopressin and renin-angiotensin systems support blood pressure after epidural block in humans. Anesthesiology 1994; 80: 1000-7.

11 Böttcher $M$, Bebrens JK, Moller EA, Cbristensen JH, Andreasen $F$. ACE inhibitor premedication attenuates sympathetic responses during surgery. $\mathrm{Br} \mathrm{J}$ Anaesth 1994; 72: 633-7.

12 Colson P. Angiotensin-converting enzyme inhibitors in cardiovascular anesthesia. J Cardiothorac Vasc Anesth 1993; 7: 734-42.

13 Colson P, Ryckwaert F, Calpet B, Raison D, Valat J, Roquefeuil $B$. Hemodynamic effect of anesthesia in patients with congestive heart failure treated with ACE inhibitors. Anesthesiology 1993; 79 : A88.

14 Mackay JH, Walker IA, Bethune DW. Amiodarone and anaesthesia: concurrent therapy with ACE inhibitors - an additional cause for concern? (Letter) Can J Anaesth 1991; 38: 687.

15 Licker $M$, Bednarkiewicz $P$, Neidhart $P$, et al. Preoperative inhibition of angiotensin-converting enzyme improves systemic and renal haemodynamic changes during aortic abdominal surgery. Br J Anaesth 1996; 76: 632-9.

16 Roden DM. Antiarrhythmic drugs. In: Hardman JG, Limbird LE, Molinoff PB, Ruddon RW, Gilman AG (Eds.). The Pharmacological Basis of Therapeutics, 9th ed. New York: McGraw-Hill Inc., 1996: 839-74.

17 Teasdale S, Downar E. Amiodarone and anaesthesia (Editorial). Can J Anaesth 1990; 37: 151-5.

18 Souter $A J$, Fredman B, White PF. Controversies in the perioperative use of nonsteroidal antiinflammatory drugs. Anesth Analg 1994; 79: 1178-90.

19 Vandermeulen EP, Van Aken H, Vermylen J. Anticoagulants and spinal-epidural anesthesia. Anesth Analg 1994; 79: 1165-77.

20 Stafford-Smith $M$. Impaired haemostasis and regional anaesthesia. Can J Anaesth 1996; 43: R129-35.

21 Ralley FE. The diabetic patient: a challenge or just routine? Can J Anaesth 1996; 43: Rl4-8.

22 Gavin LA. Perioperative management of the diabetic parient. Endocrinol Metab Clin North Am 1992; 21: 457-75.

23 Hill S, Tau K, Whitwam J. MAOIs to RIMAs in anaesthesia - a literature review. Psychopharmacology 1992; 106: S43-5.

24 Ebrahim ZY, O'Hara J Jr, Borden L, Tetzlaff J. Monoamine oxidase inhibitors and elective surgery. Cleve Clin J Med 1993; 60: 129-30.

25 McFarlane HJ. Anaesthesia and the new generation monoamine oxidase inhibitors. Anaesthesia 1994; 49: 597-9. 


\section{L'interruption préopératoire de la médication}

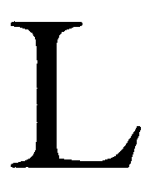

'ANESTHÉSISTE est de plus en plus fréquemment confronté à des patients affligés de plusieurs pathologies traitées avec une multitude de médicaments. Pour administrer sans danger une bonne anesthésie, l'anesthésiste doit connaître la physiopathologie de ces affections et des interactions pharmacologiques possibles. Une façon de gérer le risque dans ces conditions est de restreindre l'éventualité des interactions nocives en discontinuant les médicaments responsables avant la chirurgie. L'objectif de cette communication est de revoir la pratique de l'interruption préopératoire systématique de certains médicaments, et d'évoquer particulièrement les classes de médicaments pour lesquelles cette pratique a été encouragée ou demeure sujette à controverse.

\section{Considérations générales}

On assume qu'une médication de soutien a été prescrite dans un but spécifique, qu'elle a été optimalisée et que la condition du patient est relativement stable. L'expérience a montré que la plupart du temps, à la période opératoire, cette stabilité est assurée, quand c'est possible, par l'administration ininterrompue des médicaments prescrits.

Quand il ne semble pas possible de continuer l'administration d'un médicament avant la chirurgie, l'anesthésiste doit tenir compte de son profil pharmacologique pour s'assurer que l'intervalle sera suffisant pour son élimination métabolique. Il est possible que la présence de métabolites actifs vienne compliquer la situation.

\section{Les médicaments oraux et l'ordonnance npo}

Dans le passé, on gardait à jeun les adultes pendant au moins six heures avant une intervention pour diminuer le risque d'aspiration du contenu gastrique. L'ordre nibil per os (NPO), par erreur ou délibérément, s'appliquait souvent aux médicaments administrés par voie orale. Un examen critique a conduit au relâchement de la règle et la plupart des anesthésistes permettent régulièrement l'absorption de liquides clairs jusqu'à deux ou trois heures avant une intervention chez les patients dont le tractus digestif est fonctionnel. ${ }^{1-3} \mathrm{Par}$ conséquent, en elle-même, la condition NPO ne peut
Greg J. Doak, MD FRCPC

être considérée comme une raison valable pour cesser une médication avant une intervention. Quant aux patients dont le tractus gastrointestinal fonctionne mal, il faut faire appel à de nouveaux médicaments ou à des voies d'administration de rechange.

\section{Le systéme cardiovasculaire}

Nos appréhensions à l'égard des réactions aux agents anesthésiques, des dérangements hydriques et des manipulations du système sympathique en présence de médicaments agissant sur le système cardiovasculaire ont cédé devant la preuve que le maintien sans interruption des antihypertenseurs et des antiangineux à la période préopératoire était profitable. En particulier, si on continue d'administrer la plupart des antihypertenseurs et des antiangineux, les syndromes associés au retrait subit des $\beta$-bloqeurs des $\alpha_{2}$-mimétiques sont écartés et, de plus, le risque d'hypertension ou d'ischémie du myocarde diminue pendant l'intervention.

Les inbibiteurs du système rénine-angiotensine (SRA)

Le SRA constitue un mécanisme homéostatique de contrôle de la pression artérielle qui entre en action lorsque l'organisme perçoit une baisse du volume sanguin efficace. Cette baisse déclenche une cascade biochimique qui atteint son apogée avec la formation de l'angiotensine II. L'effet immédiat de l'angiotensine II, grâce à la médiation du récepteur de l'angiotensine II $\left(\mathrm{AT}_{1}\right)$, est une réponse vasomotrice rapide, causée par la vasoconstriction et l'amplification des effets adrénergiques périphériques. Une deuxième réponse vasopressive plus lente est provoquée par la stimulation de la sécrétion d'aldostérone et la réabsorption du $\mathrm{Na}^{+}$et de l'eau qui permettent l'augmentation du volume intravasculaire. ${ }^{4,5} \mathrm{Le}$ rôle joué par le SRA dans le maintien du volume sanguin chez le sujet hydraté dont la natrémie est normale est minime.

Les inhibiteurs de l'enzyme de conversion de l'angiotensine (IEC), qui bloquent le SRA, sont devenus la pierre angulaire du traitement de l'insuffisance cardiaque congestive et même de l'insuffisance coronaire. ${ }^{4} \mathrm{La}$ continuation des IEC à la période préopératoire a été remise en question après qu'on eut rapporté de l'hypotension profonde et subite avec ou sans tachycardie 
pendant l'anesthésie de patients sous IEC. ${ }^{4}$ Par la suite, des comptes rendus d'études cliniques se sont ajoutés confirmant l'hypotension et la faiblesse de la tolérance à l'hypovolémie pendant l'anesthésie. ${ }^{6,7} \mathrm{Il}$ en est résulté que plusieurs anesthésistes ont décidé de discontinuer les IEC avant la chirurgie. ${ }^{8}$

Pendant l'anesthésie générale et régionale centrale, le maintien de la pression artérielle et du débit cardiaque dépend en partie du SRA ${ }^{9,10}$ mais est aussi influencé par le volume sanguin, l'activation du système nerveux sympathique (SNS) et la sécrétion de la vasopressine..$^{10}$ En outre, le SRA peut affecter les réponses à l'activation du SNS directement, étant donné que l'IEC, en prémédication, atténue de façon importante la libération de la noradrénaline en réponse au stress chirurgical. ${ }^{5,11} \mathrm{Ces}$ systèmes interagissent incontestablement pour maintenir la pression artérielle, et la baisse de l'influence d'un facteur (par ex., l'intégrité de la volémie) est compensée par l'augmentation de l'activité des autres facteurs. Le blocage simultané de plusieurs des ramifications du système homéostatique par hypovolémie, suppression du SNS par l'anesthésie générale ou régionale, et le blocage du SRA par un IEC, ne laisse que de faibles moyens pour compenser et la pression artérielle s'effondre.

Des études cliniques ont montré avec régularité que l'hypotension survenait plus souvent et s'intensifiait à l'induction de l'anesthésie chez des patients qui prenaient des IEC avant une intervention que chez ceux qui prenaient d'autres antihypertenseurs ou dont la médication à l'IEC avait été cessée. ${ }^{6,7,12} \mathrm{La}$ chute de pression artérielle s'accompagne d'une baisse de la résistance systémique et des pressions de remplissage centrales et, d'habitude, répond bien à l'hydratation et aux vasopresseurs à doses modérées. Les hypertendus soumis à une intervention cardiaque ou vasculaire majeure sont particulièrement sujets à ces épisodes d'hypotension. ${ }^{6,12} \mathrm{Par}$ contre, les insuffisants cardiaques traités avec des IEC jusqu'au jour de la chirurgie présentent une faible incidence d'hypotension au moment de l'induction de l'anesthésie. ${ }^{13}$ Les hypertendus traités avec un IEC associé à deux hypotenseurs ou plus, sont davantage susceptibles de faire de l'hypotension au moment de l'induction. ${ }^{6}$ Ceci peut traduire la gravité de la maladie ou l'effet synergique de plusieurs médicaments. Les patients qui prennent un IEC en même temps que de l'amiodarone risquent de présenter de dramatiques chutes de pression. ${ }^{14}$

Bien que l'activation du SRA contribue à maintenir la pression artérielle pendant l'anesthésie, la chirurgie est un activateur du SRA encore plus puissant, spécialement pendant l'hypotension délibérée, la circulation extracorporelle et le clampage de l'aorte. ${ }^{4}$ Sous ces conditions, l'activation du SRA peut avoir des effets délétères sur le transport de l'oxygène, la performance du myocarde et la fonction rénale. ${ }^{5}$ L'activation du SRA peut être en partie responsable de l'instabilité hémodynamique, de l'utilisation anormale de l'oxygène et du dysfonctionnement rénal associés à la chirurgie de l'aorte abdominale. ${ }^{12,15}$ Licker et al. ont montré que l'analapril à des doses inhibant l'activité des IEC à $90 \%$ améliorait considérablement le débit cardiaque et le transport de l'oxygène pendant le clampage de l'aorte. Ce qui est plus important, c'est que le débit rénal et la filtration glomérulaire étaient mieux préservés et que cet avantage persistait à la période postopératoire. La réponse sympathique au stress chirurgical peut être atténuée, ce qui représente un autre effet favorable des IEC. ${ }^{11}$

Le losartan est un antagoniste du récepteur de l'AT $_{1}$ administré po introduit récemment en Amérique $\mathrm{du}$ Nord. Les données disponibles concernant ses interactions avec l'anesthésie sont limitées mais son profil thérapeutique est identique à celui des IEC ; il est donc plausible qu'il se comporte de la même façon. Contrairement aux IEC, le losartan n'empêche pas la dégradation de la bradykinine de sorte qu'on peut spéculer que l'incidence de l'hypotension profonde sera moins élevée pendant l'anesthésie. Non antagonisée par le losartan, l'activation des récepteurs $\mathrm{AT}_{2}$ par l'angiotensine II, pourrait aussi jouer un certain rôle. ${ }^{5}$ Toutefois, des études supplémentaires sont requises pour confirmer cette hypothèse.

Le blocage périopératoire du SRA peut être associé à une hypotension profonde pendant l'anesthésie mais des données suggèrent que ces épisodes sont brefs et répondent bien à la restauration de la volémie et/ou à l'administration de vasopresseurs. Bien qu'une courte interruption du traitement aux IEC semble bien tolérée, ${ }^{7}$ le maintien périopératoire du médicament chez les patients à risque peut améliorer le débit sanguin régional et le transport de l'oxygène et protéger la fonction rénale. Il est donc raisonnable de ne pas arrêter le traitement aux IEC de façon systématique à la période périopératoire. Il faut toutefois signaler des exceptions à cette règle : le patient qui reçoit un IEC en conjonction avec de l'amiodarone, le patient qui prend plusieurs antihypertenseurs (trois ou plus) et celui chez qui même un bref épisode d'hypertension ne peut être toléré. L'importance de la normovolémie doit être soulignée pendant l'anesthésie de ceux qui reçoivent un IEC.

\section{Diurétiques}

Les diurétiques sont souvent administrés comme thérapie de première ligne pour l'hypertension et comme médication d'appoint au traitement de l'insuffi- 
sance cardiaque congestive. Les effets antihypertenseurs des diurétiques dépendent en partie des changements à long terme de la résistance vasculaire secondaires à des modifications de la natrémie. Les patients qui prennent un diurétique pour une hypertension sans gravité, un oedème déclive ou une insuffisance cardiaque congestive légère développent rarement des symptômes s'ils omettent leur médication du matin ; ils seront même reconnaissants de pouvoir s'abstenir d'uriner pendant qu'ils attendent leur admission à la salle d'opération ! Cette règle ne s'applique pas à ceux qui reçoivent le diurétique pour une insuffisance rénale chronique; il serait malvenu d'omettre la médication dans cette situation.

\section{Les antiarythmiques}

Étant donné l'incidence élevée des effets secondaires associés aux antiarythmiques, ils sont rarement prescrits pour des arythmies bénignes. Ainsi, il est injustifié de les interrompre avant une intervention. Si on exclut l'amiodarone, les effets défavorables, sous anesthésie, de la plupart des antiarythmiques (dépression cardiaque et curarisation prolongée) sont mineurs, prévisibles et traités facilement. En cas de doute quant à la toxicité d'un antiarythmique, il est prudent de s'assurer que la concentration sanguine demeure dans les limites thérapeutiques et que toute anomalie électrolytique est corrigée. Quand on anticipe un jeûne prolongé et qu'une forme parentérale du médicament n'est pas disponible, (par ex., la quinidine), il est suggéré de demander en consultation le cardiologue traitant et de considérer la substitution d'un produit de la même classe par voie parentérale (par ex., disopyramide ou procaïnamide). $\mathrm{Si}$ un traitement antiarythmique doit être discontinué pour réaliser une cartographie électrophysiologique cardiaque sous anesthésie, il faut tenir compte du $\mathrm{T}_{1 / 2} \mathrm{~B}$ du produit et des effets de ses métabolites actifs. ${ }^{16}$

L'amiodarone crée certains problèmes. Ce dérivatif iodé du benzofurane possède une structure semblable à la celle de la tri-iodothyronine. Sa toxicité ressemble à de l'hypothyroïdie et pourrait être causée par son interférence avec le fonctionnement des récepteurs de l'hormone thyroïdienne. Parmi les effets toxiques associés à son administration, il faut mentionner la fibrose pulmonaire, le dysfonctionnement thyroïdien, les neuropathies périphériques et l'hépatite. L'amiodarone a des effets bloquants $\alpha$ - et $\beta$ - adrénergiques non compétitifs, plus vraisemblablement en rapport avec la réduction de la densité des récepteurs qu'avec un changement d'affinité; l'amiodarone provoque aussi une bradycardie indépendante du blocage des récepteurs. Ces effets pourraient être responsables du collapsus cardiovasculaire qui survient sous anesthésie chez certains patients. ${ }^{14,17}$ De l'hypotension causée par une vasodilatation artérielle et veineuse intense réfractaire aux doses conventionnelles de vasopresseurs et de la bradycardie résistante à l'atropine nécessitant un pacing ventriculaire ont été le plus souvent rapportées après la circulation extracorporelle.

Produit hautement lipophile, l'amiodarone se concentre dans les tissus et est éliminée très lentement avec un $\mathrm{T}_{1 / 2}{ }^{\mathrm{B}}$ de l'ordre de semaines et même de mois. ${ }^{16}$ Cette incidence élevée d'effets secondaires est la raison pour laquelle le produit n'est administré que pour le traitement d'arythmies graves ou lorsque la thérapie de première ligne s'avère inefficace. Par conséquent, il est impossible et même inutile de cesser l'amiodarone avant une intervention pour éviter les interactions nocives qui pourraient survenir pendant l'anesthésie. Toutefois, il serait prudent d'omettre aussi toute médication administrée conjointement qui pourrait déprimer plus profondément le système cardiovasculaire (par ex., les IEC).${ }^{14}$ Les complications potentiellement fatales propres à l'association amiodarone et anesthésie ne sont survenues que pendant des interventions cardiaques. ${ }^{17}$ En face de ces patients, les anesthésistes doivent être prêts à traiter les chutes de pression et les bradycardies réfractaires avec un pacemaker.

\section{L'hémostase}

Bien qu'elle ne présente pas en elle-même une contreindication à l'anesthésie générale, une déficience de l'hémostase peut affecter la planification d'une anesthésie régionale ou accroître le risque chirurgical. Il faut considérer une grande variété de produits dont les anti-inflammatoires non stéroïdiens (AINS), l'héparine à faible dose ou en doses suffisantes pour une héparinisation complète, la warfarine et les agents fibrinolytiques. Avant une intervention, toute décision visant à interrompre un AINS ou un anticoagulant doit être basée sur l'évaluation du risque : le risque engendré par la condition sous-jacente justifiant le traitement $\boldsymbol{p s}$ celui des effets de l'anticoagulation sur les résultats de l'anesthésie et de la chirurgie.

\section{Les AINS}

Les anti-inflammatoires non stéroïdiens (AINS) sont prescrits pour une grande variété de conditions, dont les troubles thromboemboliques, l'insuffisance coronaire, et plusieurs syndromes musculosquelettiques. Ils agissent par l'inhibition de la synthèse des protaglandines. En périphérie, ils ont une activité anti-inflammatoire et analgésique, ils interviennent sur la fonction plaquettaire et prolongent le temps de saignement (altération de l'hémostase) et en certaines circonstances, ils entraînent une baisse du débit sanguin rénal. Au niveau du système nerveux central, l'inhibition de la synthèse des 
protaglandines se manifeste aussi par une activité antinociceptive.

Autrefois, on interrompait l'administration préopératoire d'un AINS par crainte de l'insuffisance rénale. Il semble bien que ce risque n'existe que chez les patients qui ont des facteurs prédisposants comme l'insuffisance cardiaque, l'hypovolémie, la cirrhose, le sepsis ou un dysfonctionnement rénal préexistant. ${ }^{18}$

L'inhibition de la cyclo-oxygénase pas les AINS a pour effet d'altérer la fonction des plaquettes et de prolonger le temps de saignement. L'anesthésiste doit s'en inquiéter à cause du risque d'hémorragie chirurgicale ou de saignement causé par la technique d'anesthésie régionale. Ce sujet a fait l'objet d'un débat étendu. 8,18-20 L'association d'un hématome rachidien et d'une anesthésie régionale centrale est rare et la littérature ne suggère pas que le traitement aux AINS contribue à augmenter ce risque. Cependant, une anticoagulation concomittante ou subséquente chez un patient recevant un AINS peut introduire un risque supplémentaire important nécessitant l'arrêt préopératoire de l'AINS. ${ }^{20}$ Par son manque de valeur prédictive sur le risque d'hémorragie, le temps de saignement ne doit pas influencer la décision de procéder ou non à une anesthésie régionale. $8,18,20$

Chez le patient traité aux AINS avant l'intervention, les risques de l'altération de la fonction plaquettaire et rénale, et du saignement gastrointestinal doivent être pondérés avec le danger des accidents cérébrovasculaires, de l'ischémie myocardique et des risques causés par le manque d'activité anti-inflammatoire et analgésique dans les cas de douleurs musculosquelettiques. En général, pour les patients qui prennent déjà des AINS, le risque de séquelles possibles causées par la continuation peropératoire des médicaments semble faible. Chez les patients qui prennent de l'aspirine pour la prévention de l'ACV ou de l'ischémie, l'importance des bénéfices dépasse largement celle du risque. La réponse est moins claire lorsqu'il s'agit de patients qui prennent des AINS pour des conditions moins sérieuses. Cependant, à moins que la chirurgie n'occasionne un risque particulier d'hémorragie catastrophique ou d'insuffisance rénale, il est raisonnable de continuer les AINS jusqu'au matin de la chirurgie.

\section{Les anticoagulants}

L'anticoagulation systémique avec l'héparine ou le coumadin se rencontre souvent chez des patients qui se présentent en chirurgie; on doit l'anticiper (avec l'héparine) pour une intervention vasculaire majeure.

L'héparinothérapie préopératoire consiste en de faibles doses d'héparine $s c$, ordinairement administrées pour la prévention des thromboembolies profondes ou en remplacement de la thérapic au coumadin pour la période périopératoire. L'héparine, une molécule de polymucosaccharide de poids moléculaire élevé forme un complexe avec l'antithrombine III qui a son tour lie les facteurs IXa, XIa et XIIa à la thrombine pour interrompre la cascade de la coagulation. Pour pallier au risque d'hémorragie, l'héparine iv est cessée avant la plupart des interventions non urgentes. La demi-vie de l'héparine est courte (une à cinq heures) et il suffit ordinairement d'arrêter l'héparine quatre à six heures avant l'intervention ; il faut toutefois vérifier si le PTT est de retour à la normale. La neutralisation rapide de l'activité héparinique par la protamine iv est quelquefois nécessaire.

L'héparinisation complète est considérée comme une contre-indication à l'anesthésie régionale alors qu'en ce qui concerne l'héparine sc, la ligne de conduite est controversée. ${ }^{8,19,20}$ En général, le risque d'hématome chez le patient qui reçoit de l'héparine $s c$ est peu élevé, mais la prudence est de mise et chaque cas doit être considéré individuellement.

Le coumadin empêche la régénération métabolique de la vitamine $\mathrm{K}$, ce qui provoque la déplétion des facteurs de coagulation dépendants II, VII, LX et X. Le coumadin est souvent administré pour le traitement et la prévention des thromboembolies veineuses et artérielles. De toute évidence, le patient sous coumadin présente un risque accru de saignement en rapport avec la chirurgie ou l'anesthésie régionale centrale. Comme la neutralisation du coumadin est lente, on conseille de l'interrompre plusieurs jours avant la chirurgie et de le remplacer dans l'intervalle par de l'héparine. Si nécessaire, il est possible de neutraliser rapidement le coumadin avec de la vitamine $\mathrm{K}$ ou du plasma frais congelé.

\section{La fibrinolyse}

La thérapie fibrinolytique (par ex., avec la streptokinase, l'urokinase, le plasmogène tissulaire, l'activateur du plasmogène tissulaire) est ordinairement réservée aux affections à potentiel fatal élevé comme l'infarctus aigu du myocarde et l'embolie pulmonaire massive. À cause du risque d'hémorragies massives, la fibrinolyse est contreindiquée avant la chirurgie. Malheureusement, plusieurs patients fibrinolysés se retrouvent en urgence à la salle d'opération pour une chirurgie cardiaque. Comme il est évidemment trop tard pour arrêter la thérapie, l'administration d'un antifibrinolytique comme l'aprotinine a été proposée pour limiter les pertes sanguines pour limiter les pertes sanguines. ${ }^{20}$

\section{Les hypoglycémiants}

Chez le diabétique, l'homéostasie glucidique nécessite l'interaction de plusieurs facteurs comme l'apport 
calorique, l'équilibre hormonal interne et les hypoglycémiants administrés (c.-à-d., l'insuline et les hypoglycémiants oraux). L'intervention chirurgicale perturbe les deux premiers et, pour maintenir l'équilibre, des ajustements aux deux autres sont nécessaires.

\section{L'insuline}

La prise en charge du diabétique insulino-dépendant (type I) programmé pour la chirurgie a été revue abondamment ailleurs. ${ }^{21,22}$ Les altérations métaboliques induites par le stress et les modifications de l'apport calorique rendent difficile la prédiction des besoins insuliniques chez les patients chirurgicaux. Pendant une intervention prolongée, l'absorption de l'insuline peut devenir imprévisible à cause des altérations du débit sanguin local induites par les changements de l'hémodynamique et de la température corporelle. Chez le patient insulino-dépendant, l'approche la plus rationnelle consiste à substituer à la dose $s c$ matinale habituelle une perfusion iv continue d'insuline et de dextrose réglée sur des analyses répétées de la glycémie. ${ }^{21,22}$

\section{Les bypoglycémiants oraux}

Les diabétiques non insulino-dépendants (type II) ont de l'insuline endogène mais y sont relativement résistants. Ils sont moins sujets à l'acidocétose diabétique et leurs fluctuations glycémiques sont moins marquées. Pendant la période qui entoure l'intervention, on évitera la déshydratation et l'hyperosmolarité ou l'hypoglycémie, ce qui est plus important que de maintenir un contrôle étroit sur la glycémie. Le traitement du diabète de type II consiste souvent à administrer des hypoglycémiants oraux, dérivés de la sulfonylurée ou des biguanides.

Les hypoglycémiants les plus souvent utilisés sont les sulfonylurées. Ils stimulent la libération de l'insuline par le pancréas et réduisent la clearance hépatique de l'hormone, ce qui en augmente secondairement le niveau. Les sulfonylurées peuvent provoquer une profonde hypoglycémie, surtout chez le sujet à jeun, en rapport avec la longueur de leur demi-vie. La chlorpropamide a une demi-vie de 24 à $48 \mathrm{~h}$ alors que ses analogues de seconde génération comme le glyburide et le glizipide ont des demi-vies de trois à six heures, quoique leur activité hypoglycémiante puisse se prolonger jusqu'à 12 à $24 \mathrm{~h}$. À cause de cette disposition à provoquer de l'hypoglycémie, les hypoglycémiants oraux devraient être cessés avant la chirurgie. Les produits à durée d'action prolongée comme la chlorpropamide devraient être discontinués le jour qui précède la chirurgie. Il est suffisant d'omettre la dose de gliburide et de glipizide le matin de la chirurgie si le patient a droit à un petit déjeuner fluide ou si l'in- tervention a lieu plus tard dans la journée; pour la chirurgie programmée tôt le matin, il suffit d'omettre la dose du soir précédent. L'hydratation iv et un monitorage fréquent de la glycémie sont suggérés.

La metformine est le seul biguanide disponible. Techniquement, c'est un antitihyperglycémiant plutôt qu'un hypoglycémiant et, même à hautes doses, la metformine ne provoque pas d'hypoglycémie. La baisse de la glycémie s'effectue par l'augmentation des effets de l'insuline sur les tissus périphériques et l'inhibition de la gluconéogénèse. Comme elle ne cause pas d'hypoglycémie, il n'est pas nécessaire d'habitude de cesser la metformine avant l'intervention ; elle peut cependant causer de l'acidose lactique chez les patients soumis à un jeûne prolongé, ce qui, dans certaines circonstances exclut son utilisation.

\section{Le système nerveux}

La pharmacopée du système nerveux central comprend des médicaments contre les crises convulsives, les troubles de la motricité comme le parkinsonnisme et les troubles psychiatriques. Avec l'anesthésie, les réactions défavorables attribuées à la plupart de ces produits sont bien décrites et on peut les éviter en interrompant le traitement avant l'intervention. ${ }^{8}$ Les inhibiteurs de la monoamine oxydase (IMAO) utilisés dans les troubles affectifs font exception à cette règle.

\section{Les inbibiteurs de la monoamine oxydase}

La monoamine oxydase (MAO) est un enzyme intracellulaire responsable pour le métabolisme des catécholamines tels que la dopamine, la sérotonine et la noradrénaline. L'inhibition de cet enzyme par les IMAO provoque une accumulation de ces neurotransmetteurs dans le pool de relargage.

On a décrit trois types de réaction pendant l'anesthésie chez les patients sous IMAO. ${ }^{23-25}$ Les sympathomimétiques à action indirecte comme l'éphédrine peuvent provoquer des crises hypertensives en libérant de grandes quantités de noradrénaline, ce qui n'est pas le cas des produits à action directe comme la phényléphnine. Les deux autres types de réaction sont associés à l'administration des morphiniques. La première et la plus grave a été le plus souvent rapportée avec la mépéridine et le dextrométhorphan et se manifeste par un état d'excitation accompagné d'hypertension, d'hyperpyrexie, de rigidité, de convulsions et de coma. La deuxième manifestation, un état dépressif, a aussi été décrite avec les IMAO associés aux morphinique. Elle est caractérisée par de la dépression respiratoire, de la léthargie, de l'hypotension et du coma, et peut être secondaire à l'élévation des concentrations morphiniques causée par l'altération des enzymes microsomiques hépatiques. 
Cette possibilité d'interactions fatales avec les IMAO a donné naissance au dogme de l'arrêt complet des IMAO avant la chirurgie sous anesthésie. ${ }^{23,24}$ Les IMAO de la première génération, la tranylcypromine, la phénelzine, la pargyline et l'isocarboxazide n'étaient pas sélectifs (il existe deux isoenzymes de la MAO, la MAO-A et la MAO-B lesquelles possèdent des affinités différente pour le substrat), ni réversibles. Par conséquent, on recommandait une période d'abstinence de deux à trois semaines, tout en admettant la possibilité de séquelles psychiatriques.

Récemment des inhibiteurs spécifiques et réversibles de la MAO (IRMA) ont été introduits. Bien que les données concernant leur interaction avec les anesthésiques soient limitées, on a suggéré que ces médicaments réagissaient moins avec la mépéridine. ${ }^{23} \mathrm{La}$ courte demivie des nouveaux IRMA $\left(\mathrm{T}_{1 / 2}{ }^{B}\right.$ de deux heures pour la moclobémide) rend leur arrêt préopératoire plus facile.

L'expérience La plus récente avec les IMAO montre que l'anesthésie peut se dérouler en toute sécurité si on s'absteint d'administrer les agents déclenchants connus sans recourir à l'interruption des IMAO. Comme solution de rechange avec les IRMA, l'arrêt du médicament le jour de la chirurgie est vraisemblablement suffisant pour limiter les réactions anesthésiques défavorables sans détérioration de l'état psychique. ${ }^{25}$

\section{Conclusions}

Dans la majorité des cas, les patients devraient continuer de prendre leur médication habituelle. Des exceptions ont été formulées. Il est encore plus important de reconnaître les interactions défavorables avec l'anesthésie qui peuvent survenir et de modifier les techniques anesthésiques en conséquence. Quand il devient nécessaire de cesser l'administration d'un médicament avant l'intervention, pour prévoir la décroissance de son activité, il faut connaître la $T_{1 / 2} B$ et le comportement des métabolites. Quand on permet aux concentrations des médicaments de diminuer avant une intervention, il faut anticiper une recrudescence des symptômes. Il semble pertinent de communiquer avec le chirurgien et le médecin traitant.

\section{Références}

